\title{
Sławomir Zatwardnicki, Ateizm urojony. Chrześcijańska odpowiedź na negacje Boga, Kraków 2013, ss. 226
}

Richard Dawkins ostrą i gwałtowną krytyką chrześcijaństwa, zawartą w książce Bóg urojony z 2007 roku, wzbudził dyskusję na temat „,nowego ateizmu”. Polemikę z Dawkinsem podjęli Alister McGrath i Joanna Collicutt McGrath w publikacji Bóg nie jest urojeniem. Ztudzenie Dawkinsa z 2007 roku. Po nich powstawały liczne artykuły, dzieła zbiorowe poruszające to zagadnienie. Na uwage zasługuje publikacja Sławomira Zatwardnickiego pt. Ateizm urojony. Chrześcijańska odpowiedź na negację Boga, wydana w Wydawnictwie „M” w 2013 roku.

Zamiarem autora było stworzenie apologii Boga. Podołać temu zadaniu miały rozważania ujęte w sześciu rozdziałach: 1). Wyzwania ze strony niewierzacych (wedtug Michaela Novaka); 2). Bóg urojony? Karykatura Dawkinsa; 3). Ateizm urojony. Portret barbarzyńcy; 4). Bóg rzeczywisty. Ikona Niewidzialnego; 5). Apologia. Wezwanie dla wierzacych; 6). Ku przestrodze. Wiara urojona. Wprawdzie książka nie wpisuje się w paletę dostojnych dzieł apologetycznych Ojców greckich czy apostolskich, ale nie można jej odebrać waloru dyskursu religijnego. Autor posługuje się bowiem językiem żartobliwym, niekiedy pełnym ironii, lecz nie infantylnym. Dowcipny ton wypowiedzi podyktowany został nowymi czasami, wymagajacymi nowych form adwersacji. Wywód posiada cechy tekstu apologetycznego: źródłem jego powstania są ateistyczne oskarżenia, opiera się na doktrynie apologii, tj. jedyność Boga, moralność, Nowe Przymierze.

Cel powstania publikacji Sławomir Zatwardnicki przedstawia słowami dokumentu soborowego: ,Wielu z naszych współczesnych nie dostrzega jednak zupełnie tego głębokiego i żywotnego połączenia z Bogiem albo jawnie je odrzuca, tak że ateizm należy zaliczyć do najpoważniejszych zjawisk naszych czasów i poddać dokładniejszemu badaniu" (Sobór Watykański II, Gaudium et spes 19). Badaniu zjawiska pod nazwą ,,nowy ateizm”, który tłumaczy jako ,,ateizm walczący, 
agresywny, posługujący się zwulgaryzowaną formą znanych od dawna argumentów ateistycznych" (s. 10), poświęcił omawianą książkę.

Swoją analizę autor rozpoczął od przybliżenia osoby Michaela Novaka, który w publikacji pt. Boga nikt nie widzi. Noc ciemna ateistów $i$ wierzacych z 2010 roku przedstawił argumenty współczesnych ateistów. Kontynuuje je przez dalsze paragrafy z merytoryczną konsekwencją. Zarysowany przez niego punkt wyjścia ateistycznej negacji istnienia Boga, a mianowicie problem zła, cechuje znajomość nie tylko literatury przedmiotu, ale i wynikanie psychologiczne, przez co wyłania się erudycja autora, połączona $\mathrm{z}$ wieloaspektową znajomością poruszanej tematyki.

Stawiane przez niego pytania retoryczne, jako konsekwencja doSprawozdania i recenzje głębnej dedukcji, niekiedy zdają się nużyć. W swym założeniu jednak są próbą nawiązania dialogu z czytelnikiem, by nie był on jedynie odbiorcą wiedzy w omawianym zagadnieniu, lecz mógł, poprzez zaangażowanie umysłu, podążyć z autorem drogą odkrywania ideologii ateistycznej, za którą kryje się konkretna osobowość ludzka, którą należy zgłębić, w celu dotknięcia istoty bezbożnego światopoglądu.

Autor dokonał rozróżnienia ateizmu na antropologiczny, scjentystyczny i dogmatyczny, w tym ostatnim upatrując największe zagrożenie, ze względu na barbarzyńskość ataków jego głównych reprezentantów, tj. Richarda Dawkinsa i Christophera Hitchensa.

Polemika jest obecna w całej publikacji. Charakteryzuje się wnikliwością badawczą, precyzją argumentacji. Krok po kroku Zatwardnicki obala ateistyczne tezy, demaskując ich „opętanie materializmem” (s. 55). Stąd tłumaczy użycie określenia „ateizmu urojonego”: „Jeśli «nowy ateizm» nazywam urojonym, to dlatego, że jego reprezentanci okazują się bardziej barbarzyńscy niż można było się tego spodziewać po osobach dokonujących życiowego wyboru" (s. 75).

Po omówieniu źródeł i istoty „,nowego ateizmu”, wzorem teologii pastoralnej, autor formułuje metody walki z tym zjawiskiem. Wśród nich wymienia: zgodę na to, by Bóg był sobą (s. 131), ukazywanie Boga jako przyjaciela każdego człowieka (s. 138), umiłowanie Boga i Kościoła (s. 144), odniesienie biblijnego słowa do współczesnej egzystencji (s. 145), ograniczenie aktywizmu na rzecz żywej obecności (s. 171), praktykowanie rozumnej wiary (s. 173), odczytywanie znaków czasu: tendencji kreacji Boga starotestamentalnego, głęboko zakorzenionego indyferentyzmu (s. 177-180). W oparciu o wyżej wymienione postulaty, autor formułuje wniosek: „Na pierwszym miejscu należy postawić budzenie wiary, a dopiero na drugim - apologię, która sama w sobie nie doprowadzi nikogo do wiary” (s. 181), gdyż „niewiara współczesna 
idzie dokładnie po śladach objawiającego się Boga, tyle że w odwrotnym kierunku [...]. Odrzucenie tego objawiającego się Boga poszło szlakiem łagodzenia zgorszenia tak bliskim Bogiem" (s. 177).

Konkluzja ta winna stać się drogowskazem w sporze $\mathrm{z}$ ateistami, którzy nie są sensu stricte wrogami, lecz ludźmi poszukującymi. Dialog z nimi zatem, zdaniem autora, powinien stać się misją ewangelizacyjną. Ma być ona oparta nie na nawróceniu, lecz służbie (s. 195).

Dzięki apologetyczno-pastoralnemu charakterowi książki, czytelnik znajduje skarbnicę materiałów o „nowym ateizmie”: potrzebną wiedzę i konkretne metody działania, przydatne nawet w codziennych spotkaniach z ludźmi wątpiącymi czy niewierzącymi. Dzięki temu dualizmowi publikacja wpisuje się w nurt „nowej ewangelizacji”, wychodzącej naprzeciw „nowemu ateizmowi” i jest cennym głosem w dyskusji o tym światopoglądzie, któremu poświęca się coraz więcej wypowiedzi jako postmodernistycznemu zjawisku. Jako wypowiedź apologetyczna wyczerpuje temat polemiki z twórcami ateizmu. Jako książka o wydźwięku pastoralnym nie jest ostatnim słowem w tej kwestii, skłania jednak do myślenia i stanowi punkt wyjścia w wypracowywaniu metod przeciwdziałania ateizmowi.

Ks. Andrzej Proniewski 